\title{
ガンマ線照射掦げかま伍このアミノ酸含量および その貯蔵中における変化
}

奥 忠 武*

\author{
The Amino Acid Content of Gamma-Irradiated Fried Kamaboko \\ and the Change during Storage
}

(Changes in the Components of Gamma-Irradiated Fried Kamaboko Part I)

Tadatake $\mathrm{OKu}^{*}$
* Department of Agricultural Chemistry, College of Agriculture and Veterinary Medicine, Nihon University 34-1, Shimounia 3-chome, Setagaya-ku, Tokyo, 154

\begin{abstract}
In order to examine the changes in the amino acid content of fried Kamaboko (fried fish cake) by gamma-irradiation and by storage, samples of fried Kamaboko and its extractives were analysed using amino acid analyzer. Fried Kamaboko was prepared mainly from frozen ground Alaska pollack, packed and sealed under air in a cellophane film bag coated with polyvinylchloride. It was irradiated with a dose of $3 \mathrm{kGy}$ and subsequently stored at $10^{\circ} \mathrm{C}$ for 56 days and $30^{\circ} \mathrm{C}$ for 21 days. The results obtained were as follows: (1) Eighteen individual amino acids of fried Kamaboko showed no loss as a result of irradiation. A small quantity of methionine sulfoxide and sulfone was formed by irradiation. (2) The total bacterial count per $\mathrm{g}$ of the irradiated sample was $<30$ before storage, and it was $10^{4} \sim 10^{6}$ after $6 \sim 7$ days at $30^{\circ} \mathrm{C}$ and over $10^{7}$ after 14 days. The reduction of the total amino acid content (TAAC) of the irradiated sample was negligibly small after 14 day and about 4.5\% after 21 days. The TAAC of the extractives increased rapidly up to 3.5 times that of 0 day's. (3) During 56 days storage at $10^{\circ} \mathrm{C}$, there was no apparent change in the TAAC of the irradiated sample and also of the extractives. The combined treatment of irradiation and low temperature storage was found to be fairly effective.

(Received Jul. 12, 1982)
\end{abstract}

水産ねり製品はタンパク含量が高く，かが国特有の加 工食品である。その生産量は年約 100 万トンと多く，蒸 し板かまぼてちくわ，揚げかまぼてが主製品である。 これらは本来貯蔵性をむたせることを目的として製造さ れてきたものであるか，タンバク它主原料とした高含水 量の多成分製品であるため，腐敗細菌の好培養基であり， ネトも発生し易く貯蔵性に乏しい。

水産ねり製品に対する放射線殺菌の実用化を考える場 合，殺菌効果とともに栄養成分の低下，特にアミノ酸含 量の变化を考虑しなければならない。また，揚げかまぼ この場合は, 油の変質も重要な問題である。
菌学的立場からはすでに種々検討され，かまほこに適 する照射線量が $3 \mathrm{kGy}$ でること や蒸し板かまほ こ122，ターシング詰かまほこご，リテーナー成形かまほ こさおよび揚げかまぼこら6) の場合，いずれる殺菌効果 が高く貯蔵期間の延長が計れることなどが報告されてい る。また，蒸し板かまほこではバッケージ照射した場合 の吸収分布”についても検討されている。

一方，かまぼこ類の主要な栄養成分であるてミノ酸の 照射による减少や揚げかまぼこ中の油の照射に伴う変質 に関しては未だ十分には検討されていない。さらに，照 射かまほこ家貯藏した場合，腐敗細菌の増殖にともない，

†ガンマ線照射揚げかまとの成分変化（第 1 報）

* 日本大学㽞獣学部宸芸化学科（广 154 東京都世田谷区下馬 3-34-1) 
これらの栄養成分がどのように変化するかを同時に測定 した報告も見当らない。

本報では，かまほこ製造原料として最す一般的なスケ トウタ゚ラ冷凍すり身を主原料とした揚げかまぼについ てガンマ線照射を行ない，そのフミノ酸含量と総菌数を 非照射品と比較し，次に，照射品の貯蔵中における変化 について検討した。

また，揚げかまほこの構成タンパクは照射や腐敗細菌 により分解されて，エキス中にぺプチドやアミノ酸など として易溶化されるので，各試料のエキス中のアミ，酸 含量を調べ，揚げかまほこタンパクの变化を検討した。

\section{実 験 方 法}

\section{1. 試料}

揚げかまほこは,スケトウダラ(Theraqra chalcoromma) 冷凍すり身 SA 級 (大洋漁業(株), 洋上物) と C 級 (北 海道漁連，陸上物）を主原料としたるのである。その原 料組成は，SA 級 50.0, C 級 50.0 (いずれも $5 \%$ の砂糖, $4 \%$ Dーソルビットールと $0.2 \%$ のポリリン酸塩を含 有), 食塩 3.4 , 馬鈴薯デンプン 8.0, グルコース 1.0 , 砂 糖 3.3，シーズニング 2.0 と水 12.0 部である。これは市 販品と同じ一般的な組成であり，保存料や殺菌绪は無添 加である。この組成は伊藤ら れを十分すり上げた後, $7 \times 5 \times 0.9 \mathrm{~cm}$ の大きさに成 形し, 大豆油を用い $110 \sim 120 \pm 5^{\circ} \mathrm{C}$ で 5 分, 次いで $160 \pm$ $5{ }^{\circ} \mathrm{C}$ で 1.5 分揚げ，窒温まで放冷後 $\mathrm{K}$ セロフォ袋を用 い1個ずつ含気包装した。

\section{2. 照射条件}

試料は包装後直ちに $5^{\circ} \mathrm{C}$ 半日保ち, 当日から 翌日 にかけて東海区水産研究所のCo 60 ガンマ線照射装置 $(1070 \mathrm{Ci})$ を用い，室温 $\left(17^{\circ} \mathrm{C}\right)$ て適正線量 ${ }^{1)}$ といわれ る $3 \mathrm{kGy}$ の照射を行なった。

\section{3. 貯茂条件}

試料の貯蔵は,低温の $10^{\circ} \mathrm{C}$ て 56 日間をたは高温の $30^{\circ} \mathrm{C}$ で21 日間である。

\section{4. 粗タンパク，水分と $\mathrm{pH}$ の測定}

粗タンパクは常法のセミ・ミクロ・ケルダール法で, 水分は常法の $105^{\circ} \mathrm{C}$ 乾燥法で測定した。 $\mathrm{pH}$ はニードル 形複合電極（堀場 No.6201-10 T型）を試料の切口を変 えながら数個所に差込み測定をし，平均值を求めた。

\section{5. 総菌数の測定}

試料の包装袋の表面をエタノールを合んだ綿で拭い， 開封後試料をハサミで細切し，この $5 \mathrm{~g} に 45 \mathrm{ml}$ の滅菌 水を加光ホモジナイズした上澄を原液とする。原液 1 $\mathrm{m} l$ を $9 \mathrm{~m} l$ の滅菌水に加え，さらに段階的に 10 倍希釈 をくり返し，各希 釈液につき標準寒天培地（日本製芘 （株）製，酵母エキス $2.5 \mathrm{~g}$ ，ペプトン $5.0 \mathrm{~g}$ ，グルコース $1.0 \mathrm{~g}$, 寒天 $15.0 \mathrm{~g}$, 滅菌水 $1 l$, 塩化ナトリウム $20.0 \mathrm{~g}$, $\mathrm{pH} 7.0$ ) を用いて，常法 (平板培養法で $36 \pm 1^{\circ} \mathrm{C}, 48$ 時 間培盖)により総菌数を測定した。試料は，同一貯蔵条 件のあのから任意に 2 個（2袋）を選んだ。

6. アミノ酸分析

(1) エキスの調製 ${ }^{8}$

試料を 2 個用いてそれぞれを 4 等分し，異なる部位の 4 片ずつ，才なわち 1 個分相当約 25〜30 g 精科した。 これをホモジナイザーで汾砕後，3倍量の $80 \%$ エタノー ル $(\mathrm{v} / \mathrm{v})$ で $80^{\circ} \mathrm{C}, 30$ 分の攪拌抽出後, $5000 \mathrm{rpm}$ で 20 分遠心分離して上澄を集めた。残渣に対して同様の抽出 を 2 回，合計 3 回抽出を行ない，これら家せてェキス 試料とした。このエキス試料を $35^{\circ} \mathrm{C}$ 以下で減圧濃縮して $25 \mathrm{~m} l$ に定容し，以下の加水分解用試料とした。

(2) 加水分解

加水分解に用いた試料量は，固形の揚げかまぼこでは $1 \mathrm{~g}$ ，また上記エキスの場合は $5 \mathrm{ml}$ である。トリプトフ フン以外のアミノ酸については常法に従って,試料に $6 \mathrm{~N}$ 塩酸を加光, $110^{\circ} \mathrm{C}, 20$ 時間，脱気封管中で加熱し，次 に $35^{\circ} \mathrm{C}$ 以下で減压濃縮乾固し，クェン酸釋衝液 $(\mathrm{pH}$ 2.2）により希䣋してアミ，酸定量用検体とした。一方， シスチンの定量用検体は，あらかじめScHRUMらの過 蟻酸酸化法 ${ }^{9)}$ でシスティン酸にした後に，上記加水分解 を行なった。

トリプトフォンの定量では，試料をデンブン含有 $4.2 \mathrm{~N}$ 水酸化ナトリウム溶液中で処理する HUGLI らの方法 ${ }^{10}$ に準じた。これらのいずれの加水分解も2 連で行なっ た。

(3) アミノ酸の定量

各検体 $(0.5 \mathrm{ml})$ をアミノ酸自動分析計（日立 KLA5 型）に添加し分析した。

\section{実験結果および考察}

\section{1. 照射揚げかまぼこ}

（1）粗タンパク，水分， $\mathrm{pH}$ および総菌数 照射品の粗タンパク，水分， $\mathrm{pH}$ および試料 $1 \mathrm{~g}$ 当り の総菌数は，それぞれ $12.2 \% ， 67.9 \% ， 6.59$ およびく30 で，非照射品のそれら証それぞれ $12.0 \% ， 68.1 \%, 6.62$ およびく30であった。粗タンバクと水分含量は，日本食 品成分表の值 ${ }^{11}$ (それぞれ試料 $100 \mathrm{~g}$ 当り $12.3 \mathrm{~g}$ と 66.2 g）と近似した結果であった。この結果から,照射による 
Table 1 Amino acid content of fried Kamaboko before and after irradiation

(mg/100g sample)

\begin{tabular}{|c|c|c|c|c|c|}
\hline \multirow{2}{*}{$\begin{array}{l}\text { Amino } \\
\text { acid }\end{array}$} & \multicolumn{2}{|c|}{ Unirradiated } & \multicolumn{2}{|c|}{ Irradiated $(3 \mathrm{kGy})$} & \multirow{2}{*}{$\begin{array}{c}\text { Reference } \\
\text { data }^{2)}\end{array}$} \\
\hline & Mean & $\begin{array}{c}\text { Experimental } \\
\text { error }{ }^{1)}(\%)\end{array}$ & Mean & $\begin{array}{c}\text { Experimental } \\
\text { error }(\%)\end{array}$ & \\
\hline Glu & 1844.5 & 4.0 & 1835.3 & 3.5 & 1750 \\
\hline Asp & 1314.9 & 2.3 & 1299.1 & 3.0 & 1500 \\
\hline Lys & 1107.0 & 1.9 & 1084.9 & 1.6 & 1030 \\
\hline Leu & 917.7 & 4.4 & 916.8 & 3.4 & 830 \\
\hline Arg & 789.0 & 2.1 & 756.7 & 2.2 & 730 \\
\hline Ala & 663.7 & 2.7 & 655.7 & 1.3 & 610 \\
\hline Ileu & 561.5 & 4.7 & 549.7 & 4.1 & 540 \\
\hline Val & 545.6 & 3.4 & 535.8 & 3.3 & 400 \\
\hline Thr & 458.2 & 3.7 & 453.2 & 2.3 & 480 \\
\hline Gly & 452.1 & 0.4 & 451.2 & 1.7 & 440 \\
\hline Phe & 437.3 & 2.2 & 420.2 & 3.0 & 420 \\
\hline Tyr & 402.5 & 2.4 & 392.4 & 3.0 & 360 \\
\hline Ser & 358.1 & 3.9 & 354.2 & 5.0 & 380 \\
\hline His & 345.4 & 3.4 & 338.5 & 5.4 & 310 \\
\hline Met & 321.6 & 2.2 & 306.5 & 4.2 & 310 \\
\hline Pro & 309.4 & 4.6 & 298.6 & 3.7 & 400 \\
\hline Cys & 130.1 & 5.9 & 125.2 & 10.9 & 120 \\
\hline Try & 102.1 & 3.7 & 100.1 & 9.2 & 90 \\
\hline Total & 11060.7 & 2.9 & 10874.1 & 3.3 & 10690 \\
\hline $\mathrm{NH}_{8}$ & 13.0 & 1.5 & 15.9 & 6.3 & - \\
\hline MetSO ${ }^{8}$ & 0 & - & $d^{*}$ & - & - \\
\hline $\mathrm{MetSO}_{2}^{4)}$ & 0 & - & d & - & - \\
\hline
\end{tabular}

1) Experimemtal error $=($ difference $/$ mean value $) \times 100$

2) Reference date from "The Amino Acid Composition of Foods in Japan(1966)"

3) Methionine sulfoxide

4) Methionine sulfone

* Detected

粗タンパク，水分， $\mathrm{pH}$ の变化はほとんどないととが判 った。また，照射品の外観と色調は非照射品と差が認め られなかった。

(2) アミノ酸含量

Table 1 に照射前後の揚げかをぼこのアミノ酸分析の 結果を示した。結果は 2 連で分析した平均俌と，ての実 験誤差の百分率（(差/平均）×100）で示した。表中に日 本食品了ミノ酸組成表 ${ }^{123}$ の值を対比させた。

照射による各アミノ酸の損失はなく，イソロイシンか らセリンまでの 18 種てミノ酸の含量の合計です, 損失は 実馱誤差を考虑すると認められなかった。この結果は， UNDERDAL $~^{13)}$ がタラ切身に本実験と同線量の $3 \mathrm{kGy}$ 照 射をして，15種のアミノ酸を調べた結果と類似してい
る。

Table 1 の 18 種アミノ酸以外に, 照射によりメチオニ ンの酸化生成物であるメチオニンスルホキシドおよびス ルホンが検出された。メチオニン水溶液にガンマ線照射 を行なった場合，これら以外にホモシステイン酸，木モ セりン， $\alpha$-アミノ酪酸などの生成が報告14)されている が，本実験においてはそれらは検出されなかった。

以上の結果から判断すると，揚げかまほに対して 3 $\mathrm{kGy}$ の照射を行なった場合のアミノ酸（18 種）の損失 はほとんどないものと考えられた。

(3) エキスのアミノ酸含量

エキス中のフミノ酸の分析結果は Table 2 に示した。 非照射品エキスの全アミノ酸含量は平均值で $98.0 \mathrm{mg}$ 
Table 2 Amino acid content of fried Kamaboko extractives before and after irradiation

(mg/100 g sample)

\begin{tabular}{|c|c|c|c|c|}
\hline \multirow{2}{*}{$\begin{array}{l}\text { Amino } \\
\text { acid }\end{array}$} & \multicolumn{2}{|c|}{ Unirradiated } & \multicolumn{2}{|c|}{ Irradiated ( $3 \mathrm{kGy}$ ) } \\
\hline & Mean & $\begin{array}{c}\text { Experimental } \\
\text { error }{ }^{11}(\%)\end{array}$ & Mean & $\begin{array}{c}\text { Experimental } \\
\text { error }(\%)\end{array}$ \\
\hline Glu & 15.2 & 3.9 & 13.9 & 4.3 \\
\hline Asp & 10.2 & 3.9 & 9. 3 & 4.3 \\
\hline Lys & 11.3 & 5.3 & 9.3 & 6.4 \\
\hline Leu & 6.4 & 6.3 & 5.6 & 3.6 \\
\hline Arg & 4.0 & 10.0 & 3.5 & 11.4 \\
\hline Ala & 9.2 & 2.2 & 8.9 & 4.5 \\
\hline Ileu & 3.1 & 6.5 & 2.7 & 7.4 \\
\hline Val & 4.9 & 8.2 & 4.4 & 4.5 \\
\hline Thr & 4.8 & 4.2 & 4. 2 & 4.8 \\
\hline Gly & 7.8 & 2.7 & 7.3 & 2.8 \\
\hline Phe & 4.7 & 4.3 & 3.9 & 5.1 \\
\hline Tyr & 1.7 & 11.8 & 0.8 & 12.5 \\
\hline Ser & 4.7 & 4.3 & 4.2 & 4.8 \\
\hline His & 2.3 & 8.7 & 2.0 & 10.0 \\
\hline Met & 2.6 & 7.7 & 0 & - \\
\hline Pro & 2.8 & 7.1 & 2.4 & 8.3 \\
\hline Cys & 1.7 & 11.8 & 0.9 & 11.1 \\
\hline Try & 0.5 & 12.0 & 0.3 & 13.3 \\
\hline Total & 98.0 & 5.2 & 83.6 & 5.3 \\
\hline $\mathrm{NH}_{3}$ & 13.0 & 3.1 & 15.9 & 6.3 \\
\hline MetSO'1 & 0 & - & $\mathrm{d}^{*}$ & $\ldots$ \\
\hline $\mathrm{MetSO}_{2}{ }^{8)}$ & 0 & - & $\mathrm{d}$ & - \\
\hline
\end{tabular}

1) Experimental error $=($ difference $/$ mean value $) \times 100$

2) Methionine sulfoxide

3) Methionine snlfone

* Detected

で,これは非照射品の 全アミノ酸含量の平均値 11060.7 $\mathrm{mg}$ の約 $0.9 \%$ 相当であった。

照射によるエキス中のアミノ酸の変化を平均值でみる と,メチオニンは消失, シスチン, チロシンは約半分に, トリプトファンは 40\%の消失, 他のアミノ酸は $20 \%$ 以下 の减少であり，結局，エキス中の全アミノ酸含量の照射 による減少は約 15\%であった。しかし，これは非照射品 の全厂ミノ酸含量の平均值に対して約 $0.1 \%$ 相当に過ぎ ず，実験誤差を含めて考えるとこの減少は問題にならな いものと思われる。

\section{2. 貯藏中の照射揚げかまぼこ}

(1) 粗タンパク, 水分, $\mathrm{pH}$ および総菌数の变化

揚けかまほこを照射後 $10^{\circ} \mathrm{C}$ およ゙ $30^{\circ} \mathrm{C}$ に貯藏した場 合の粗タンパク, 水分, pH の変化は Fig. 1 に, 総菌数
の変化は Fig. 2 に示した。 $30^{\circ} \mathrm{C}$ 貯藏区の pH は経日的 に上昇傾向を示したが，粗タンパク，水分， $10^{\circ} \mathrm{C}$ 貯蔵区 の $\mathrm{pH}$ には大きな変化が認められなかった。

$30^{\circ} \mathrm{C}$ 貯蔵区では，非照射品は 2 日目でネトが，3 日目 に異臭が生じ， $1 \mathrm{~g}$ 当りの総菌数は初期の变敗といわれ る $10^{516)}$ に達した。一方，照射品では照射直後く30であ ったが，泍增し6〜7日後に $10^{4} \sim 10^{6}$ に達し，ネトはみ られないがカビの発生が認められ，約半数のものに僅か に異臭が感ぜられ，14日目に $10^{7}$ 近くに達した。21 日目 に107を越し，半数以上にガスの発生に伴う包装袋の膨張 が諗められた。

$10^{\circ} \mathrm{C}$ 貯蔵区では, 非照射品は6日目に総菌数が $10^{2}$ に達 し，以降急增し，13〜14 日目にカビが発生したが，ネトは 認められなかった。照射品では，総菌数の増加速度は遅 


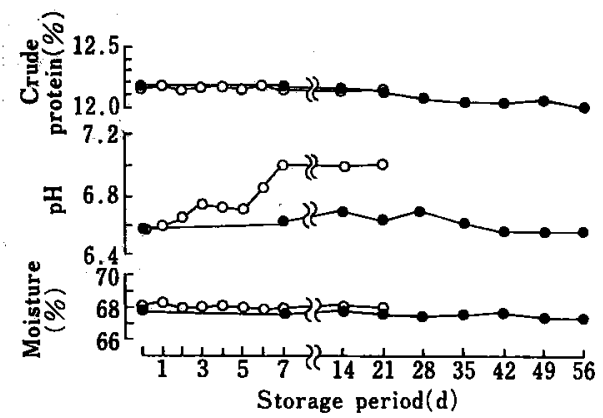

Fig. 1 Changes in crude protein, moisture and $\mathrm{pH}$ of irradiated fried Kamaboko during storage

Stored at $10^{\circ} \mathrm{C}-1$ and $30^{\circ} \mathrm{C} 0-\mathrm{O}$. Irradiated with $3 \mathrm{kGy}$.

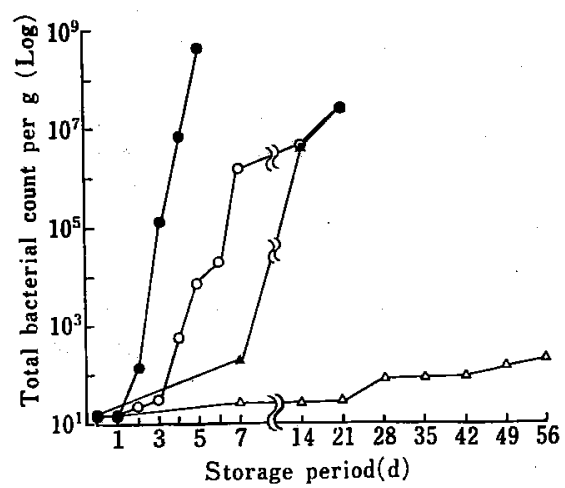

Fig. 2 Changes in total bacterial count of fried Kamaboko during storage

Storage at $30^{\circ} \mathrm{C}$ \{unirradiated $\begin{aligned} & \text { urradiated with } 3 \mathrm{kGy} \text { a-O } \\ & \text { ir }\end{aligned}$

Storage at $10^{\circ} \mathrm{C}\left\{\begin{array}{l}\text { unirradiated } \\ \text { irradiated with } 3 \mathrm{kGy} \Delta-\Delta\end{array}\right.$

延され，56 日目で $10^{2}$ 程度であり，外観的異常も認めら れず，低温貯蔵と照射の併用効果が明らかであった。

(2) $丁$ ラ 酸含量の変化

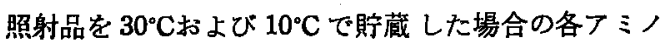
酸量の分析結果は, Fig. 3 に示した。また,各アミノ酸(18 種) 量を合計した結果とアンモニフの定量結果は Fig. 4 に示した。四中の結果は，2連で分析した平均值で，実 験誤差は垂線で表わした。Fig. 3 中には, $30^{\circ} \mathrm{C}$ 貯藏区の 1〜6 日目までの各フミノ酸量の結果が，7 日目の結果 に比べて実験誤差範囲はほぼ同じで，各含量は高い值で あったので示していない。また, $10^{\circ} \mathrm{C}$ 䝪藏区の 7, 14, 28, 35，42，49 日の各丁ミノ酸量の結果は, 照射直後の結果 と大差がなかったので示していない。

$30^{\circ} \mathrm{C}$ 貯蔵区の各フミノ酸の減少は, 平均值で見ると漸

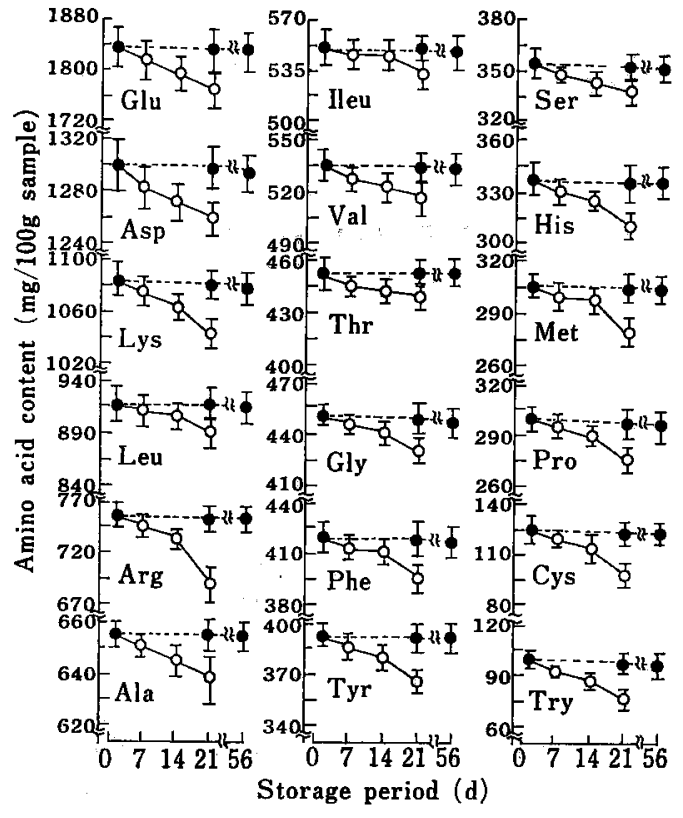

Fig. 3 Changes in the amino acid content of irradiated fried Kamaboko during storage

Stored at $30^{\circ} \mathrm{C} O-O$ and $10^{\circ} \mathrm{C} \bullet \cdots \bullet$. Irradiated with a dose of $3 \mathrm{kGy}$. Vertical lines indicate experimental errors.

减傾向であるが，実験誤差を考え併せると14 日目まで照 射直後と大差が認められなかった。21日目において，口 イシン，イソロイシン，バリン，スレオニンなどの減少 は極くわずかであったが，フルギニン，リジンや含量の 少ないトリプトフォン, シスチン, プロリン, メチオニ ンなどの減少は少量ずつ認められた。18種のフミノ酸量 の合計の平均値でみると，21 日目で照射直後の約 $4.5 \%$ の減少であった。フンモニフの生成は 21 日目で照射直 後の約 7 倍に達した。このフミノ酸の漸减する結果は, タラ肉の腐敗の場合 ${ }^{15)}$ 之類似した傾向であった。

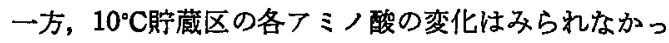
た。すなわち，揚げかまぼこに対する照射 ( $3 \mathrm{kGy})$ と 低温 $\left(10^{\circ} \mathrm{C}\right)$ 貯藏の併用勃果が顕著に認められた。

(3) エキスの全アミノ酸含量の变化

照射品を $30^{\circ} \mathrm{Cおよび} 10^{\circ} \mathrm{C}$ で睁蔵した場合のエキスの フミノ酸 (18 種) 量を測定し、合計した結果は Fig. 4 に示した。

$10^{\circ} \mathrm{C}$ 唄藏区のエキスの全フミノ酸含量の变化は見られ ず, フンモニフの生成量の增加む僅少であった。一方, 


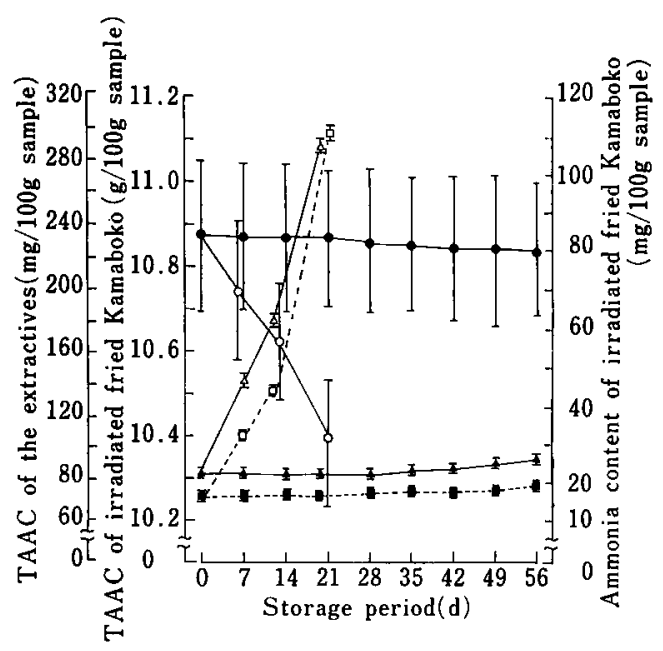

Fig. 4 Changes in the total amino acid content (TAAC) of irradiated fried Kamaboko and of its extractives during storage TAAC of the extractives during storage at $30^{\circ} \mathrm{C} \Delta-\Delta$ and $10^{\circ} \mathrm{C} \Delta-\Delta$, TAAC of irradiated fried Kamaboko during storage at $30^{\circ} \mathrm{C} \mathrm{O}-\mathrm{O}$ and $10^{\circ} \mathrm{C}-\bullet$, and ammonia content of irradiated fried Kamaboko during storage at $\square \cdots \square$ and $10^{\circ} \mathrm{C}=\cdots \cdot$.

Irradiated with a dose of $3 \mathrm{kGy}$. Vertical lines indicate experimental errors.

$30^{\circ} \mathrm{C}$ 貯蔵区の揚げかまほこのフミノ酸は, Fig. 3 に示し たように 14 日目までほほ変化が見られないが,エキスの 全アミノ酸含量は 7 日目で照射直後の約 1.8 倍に, 14 日 目で約 2.2 倍に, 21 日目には約 3.5 倍に達し，揚げかま ほこタンパクの加水分解の進行が明らかであった。

この結果，10ㄷ貯蔵区では，照射揚げかまほこタンパ クの変化はほとんど起っておらず，30 $\mathrm{C}$ 貯蔵区では，14 日目で照射品のタンパクの約 $0.9 \% ， 21$ 日目で約 $1.9 \%$ が主に微生物により加水分解，易溶化されエキス中へ移 行したことが判った。

$$
\text { 要 約 }
$$

揚げかまほこにガンマ線照射 ( $3 \mathrm{kGy}$ )を行なった場 合，また，照射品を引き続き貯蔵した場合のアミノ酸含 量の変化を調べる目的で，スケトウダラ冷凍すり身を主 原料とした揚げかまほこを用い，揚げかまぼことその工 キス中のアミノ酸量を測定した。同時に, 総菌数, 粗タ ンパクなども測り，以下の結果を得た。

(1) 揚げかまぼこの18種の個別てミノ酸の照射によ る損失はほとんどなかった。
ニンの酸化生成物であるメチオニンスルホキシドおよび スルホンが僅かに生成された。(3) 照射品の $30^{\circ} \mathrm{C}$ 貯蔵 では, $1 \mathrm{~g}$ 当りの総菌数は照射前で $<30,6 \sim 7$ 日後 に $10^{4} \sim 10^{6}$ に，21 日後に $10^{7}$ 越えた。照射品の全アミ ノ酸含量は 14 日後においても照射直後と大差がなく, 21 日後に約 $4.5 \%$ の減少が認められた。しかしながら， エキス中の全アミノ酸含量は経日的に急增し, 21 日後に 照射直後の3.5 倍に達し, 微生物による揚げかまほこタ ンパクの分解，易溶化が明らかに認められた。 (4) 照 射品を $10^{\circ} \mathrm{C} て ゙ 56$ 日間貯蔵した場合，揚げかまぼこおよ びェキス中のフミノ酸含量に顕著な变化は全く認められ ず，照射と低温貯蔵の併用効果が明白であった。

終りに, 本研究の遂行に当り終始御指導を戴いた白井 和雄教授に深謝致します。

Co-60ガンマ線照射装置の使用の御許可を下さった水 産庁東海区水産研究所の篠山茂行ならびに戸澤晴己の両 技官に対し，また総菌数測定の実験の御指導を戴いた同 篠山茂行技官に感謝致します。さらに，試料の調製を願 った株式会社紀文に対し謝意を表します。

本報告をるとるに当り，有益な御助言を睗った東海 物産株式会社食品研究所左藤友太郎所長ならびに農林水 産省食品総合研究所梅田圭司技官に感謝致します。

本報告の概要は, 1980 年 12 月第 11 回日本食品照射研 究協議会大会 (東京) で発表した。

\section{文献}

1）篠山茂行：東海水研報，No. 70, 57 (1972).

2) 篠山茂行：東海水研報，No. 75，39 (1973).

3) 篠山茂行 - 柴真 - 山本常治: 東海水研報, No. 82, 97 (1975).

4) 伊藤 均 - 飯塚 廣：日食工誌, 25, 14 (1978).

5) 篠山茂行：東海水研報，No. 87，25 (1976).

6) 伊藤 均 - Siagian, E. G.：日食工誌， 26, 342 (1979).

7) 久米民和 - 標 宏行 - 青木章平 - 佐藤友太郎：日 食工誌, 24, 72 (1977).

8) Shewan, J.M., Fletcher, L.I., Partridge, S.M. and Brimley, R. C.: J. Sci. Food Agric., 3, 394 (1952).

9) Schrum, E., Moore, S. and Bigwood, E.: Biochem. J., 57, 33 (1954)

10) Hugri, T.E. and Moore, S.: J. Biol. Chem., 247, 2828 (1972).

11）科学技術庁資源調査会編：三訂補日本食品標準成 分表 (大蔵省印刷局)， p. 78 (1980).

12）科学技術庁資源調查会編：日本食品丁ミ/酸組成 表（大藏省印刷局），p. 52 (1966).

13) UNDerdahl, B., Nordal, J., Lunde, G. and Eggum, B.: Lebensm.-Wiss. u. Tech., 6, 90 (1973).

14) Kopoldova, J., Liebster, J. and Gross, E.: Rad. Res., 30, 261 (1971).

15) Shewan, J. M. and Jones, N.R.: Food Agric., 8,491 (1957). (昭和 57 年 7 月 12 日受理) 